\title{
NBSIR 73-202
}

\section{Conservation Via Effective Use of Energy at the Point of Consumption}

Institute for Applied Technology

National Bureau of Standards

Washington, D. C. 20234

April 1973

Final Report

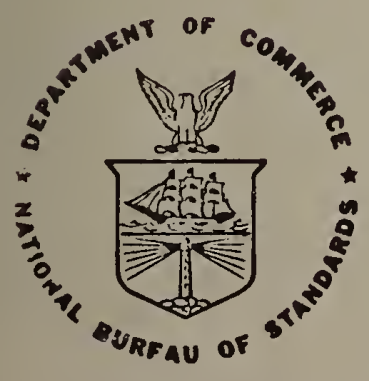

U. S. DEPARTMENT OF COMMERCE

NATIONAL BUREAU OF STANDARDS 

NBSIR 73-202

\section{CONSERVATION VIA EFFECTIVE USE OF \\ ENERGY AT THE POINT OF CONSUMPTION}

Charles A. Berg

Institute for Applied Technology

National Bureau of Standards

Washington, D. C. 20234

April 1973

Final Report

U. S. DEPARTMENT OF COMMERCE, Frederick B. Dent, Secretary NATIONAL BUREAU OF STANDARDS, Richard W. Roberts, Director 


\section{Abstrect}

Whe practices ard equipment employed at the point of energy consumption in buildings and in industrial processes psimit excessive consumption of enerky. It is estimated that if full epplication of the economically justifiable technical improvements presently availbile vere nade to equipment and practices in buildings and industry, as much 25 percent of the total primary fuel consumption in the U.S.A. courd be conserved. The reasons why economically justifiable application of effective technology at the point of energy consumption has not been widely adoptsd in the past are considered. The needs to facilitate adoption of effective equipment and practices in the future are discussed. 
Eivirotiction

With shortages of fuel and electrical power now occurring in various parts of the United States, there no longer remains serious dou't that the U.S.A. faces difficult problems in obtaining the energy needed to sustain everyday life and industry.

The basic energy problem of the U.S.A. is that consumption of high quality nonpoliuting fuels is straining the national capacity to provide these fuels. It is clear that new primary sources of energy will be required to meet ruture needs of the U.S.A. A number of new energy sources are available. These include some which require substantial technological development, such as the breeder reactor and gasified cóal. In adition, if adequate poliution control can be developed, the Vast sulphur containing anthracite reserves of the U.S.A. can be utilizea; these are estimated to be surficient to sustain the U.S.A. for 500 years or more. Also, oil and liquified natural gas can be imported. lhe options available for developing new primary sources of energy are indeed numerous and varied. However, they share a common aspect; each is costly. One example of the costliness of new sources of energy is the estimate that by 1985 U.S. inports of petroleum will represent an annual trade deficit of approximately 20 billion dollars (I).

With the passing of the era of abundant inexpensive ciean forms of primary energy, rising costs of energy alone, will compel everyone to examine the effectiveness with which energy is used, The conservation of primary sources of energy may be essential to assuring the quality of life, the economic well-being and even the national security of the U.S.A. 


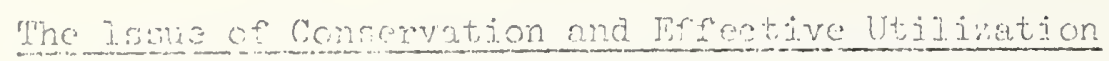

There are two basic ways to conserve energy. One is straightforward curtailment of fiels and electrical pover. * The other is improvonent of. the efficiency at the point of consumption. Until recently it has not been widely recognized that improvement in the efriciency of energy Ucilization at the point of consumption could yicid significant reductions in the national requirements for high quality fuels, without requiring sacrifices jin the comfort, safety or health of building occupants or in the producitivity of industrial processes. Ultimately, effective measures for conservation will probably require both curtailment and improveInent of efficiency of energy consumption. But if the potential for energy conservation through efficient utilization at the point of consumption is recognized and developed, programs of conservation can be instituted with far less stringent effect on industry and society than if conservation were to be attempted through curtailment alone.

Any approach toward economic optimization of the national. energy system will require careful examination of the effectiveness with which energy is used at the point of consunption; it does not make good sense, neither in economic terms nor in any other, to continue excess consumption of significant quantities of a vital and increasingly costly natural resource, through ineffective practices.

\footnotetext{
Fit the moment, several resions in the U.S.A. are living under a fuel rationing system, acministered by the fuels industry which presently finds itself unabie to meet the full demand of repional markets. The mechanism of conservation through curtailment is already being put to use.
} 


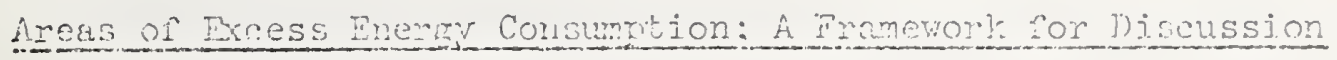

I'o identify areas in wich signiłicant energy savings are possivle one must know how much energy is consumed in various practices and how effectiveiy the energy is consumed. The second guestion, with what efrectiveness is energy consumed, involves technical issues to be discussea later. But, the basic data required to answer the first question has been compiled by Stanford Research ${ }^{-I n s t i t u t e ~ i n ~ t h e i r ~ r e p o r t ~ t o ~ t h e ~ O f f i c e ~}$ cf Science and Technology, entitled Patterns of Energy Consumption in the U.S. (2). The sumary data of the report, which are given in Table $I_{\text {, }}$ provide an itcmized breakdown of the amount of energy consumed in various practices tinroughout the U.S.A. (2). These data represent the most recent and one of the more reliable attempts to account for the use of energy at the point of consumption.

The datc of Table I reveal several significant aspects of energy consumpion. First, there are three main areas of energy consumption-building services, industrial processes, and transportation. of these, transportation has been the subject of publis scrutiny by government agencies, public interest groups, industry and academic institutions. Energy use of transportation is being investigated at many levels and will not be further treated here. 
Fowever, the potential for conservation through improved practices of enerey consuntion in builaings and in industrial processes has recured small notire until recentily. * Actually, both building services ard industrial procteses consume vast quantities of encregy, and in both areas irelfective practices allow large quantitics of energy to escape utilization.

Table I also reveals significant comparisons between areas of energy consurption. For example, industrial electrolytic processing, which includes alumirum refining, consumes approximately 1 percent of the prinary fuels used in the U.S.A.** It is widely known that aluminum refining and other industrial electrolytic processes require large amounts of energy. However, Table I reveals that hot water heating in residences and commercial bujldings accounts for approximately 4 percent of the consumption of prinary fuels in the U.S.A. It would appear that efforts to conserve primary fuels might be as fmitfully applied to hot water heating as to electrolytic processing, even through much greater public attention has been focused on the latter. This observation really illustrates a basic noint which is reflected numerous tiries by the data of Table I. Many of the seemingly mundare practices of everyday life, such as hot water heating, space heating, and cooking consume vast

\footnotetext{
* In fact, in many quarters it has been assumed that significant improvements of practices in these fields were either technologically infeasible or economicaily unjustifiable. Neither of these assumptions is warrantea. * The data of Table I indicate the fuel requirea to provide electrical energy.
} 
quantities of energy. The effectiveness of practices in these seeningly mundane areas is, as a rule, rather low and also rather easily correctable. Improvements in these practices offer immense opportunities for conservation of primary fuels

To broach the question of effectiveness of energy consumption, one must define both "consumption" and "effectiveness." In this paper, consumption of energy means the ultimate use of energy to operate a process or to provide a service. Specifically, consumption of energy does not mean the conversion of energy from one form to another, as in electric power generation; the energy content of the fuel required to generate electric power is viewed as being consumed at the point where electric power is ultimately put to use.

To assign an effectiveness to an energy consuming process requires some measure of the minimum energy required to operate the process. In some instances, it is possible to determine a physically irreducible minimum energy requirement for a process, as. In. the case of drying fabrics, thermal conversion of limestone to portland cement, or refrigeration of given items of food. In other instances, it is not clear whether physically irreducible minimum energy requirements can be identified.*

But in any event, while it is useful to know the physically irreduciole minimum energy requirements for energy consuming processes in buildings and industry, it is often more useful to know the amount of energy which

*For example, in space heating, heat is required to replace losses, but if perfect insulation and sealing were available, no losses would occur and no heat would be required. However, perfect insulation and draft sealing are not available, and even if they were they would be neither economically justifiable nor desirable. Perfectly sealed buildings would be unlivable. 


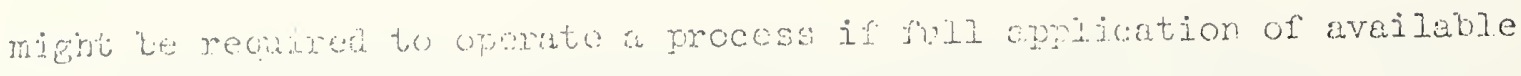
technology wero make, wo to an econonically justiriabie limit. It is this amount of cnergy which will be used hore to establish a measure of the effectiveness of a themal process. The criterion for economic justification proposed here is ninimun combined initial cost and operating cost of equipnent, including, in particular, fuel cost.*

Whe term life cycle costing is often used to describe this combination, and will be empicyed here. Appropriate discounting is, of course, to be applied in calculations of operating costs. 


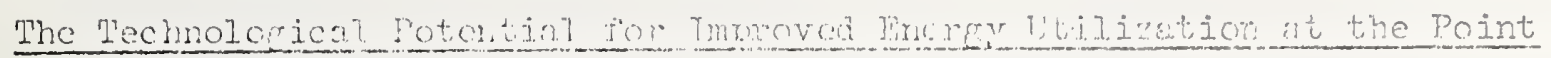
of Consumpition

A few of the outstanding examples of opjortunities for improving efrectiveness of enerey consumption in bujldings and inüustrial processes are offered here to support the plausibility of estimates of the total reduction of national requirements for high quality fuels, which might be echieved if full economically justifiable application of available technology were made to improve energy consumption practices.*

(a) Enerry Use in Buildings

The effectiveriess of energy use in builaings is aetermined by three items:

- Design (inciudin insuation, fenestration, selection of heating and ventjating equipment, ctc.)

- Construction Fractices in Irolementing Design

- Occupart Practices in Using Puiloings

Moyers (6) has studied the econcmic aspects of insulation and fenestration of residences. He detemined the savings of heat iransmission directly through the walls of a building, and calculated the life cycle costs of insulation and storm windows by combining initial costs (with suitable

\footnotetext{
*Detailed stuaies of the potential for improved energy use in buildings have been made by a number of investifators (e.g., $(3,4,5,6,7))$; in a few instances, specific possibilities for obtaining more effective consumption of energy in industrial processes have been studied in detail $(e \cdot 8 .,(8,9,10,11))$. For further data and information of greater detail, the readis is referred to these reports.
} 
interest and tares applied) with fugl costs bypical of the time at which the calculation was carried out (Igro). Pigure I shows some of Moyers data, which indicate that by using $3 \mathrm{I} / \mathrm{e}$ jnches of wall insulatjon, 6 inches of ceiline insulation and applying storm windows one cun cut the heat losses through the walls of a typical residence in New York or Minneapolis by somewhat more than 1 o percent, as comparea with the heat losses which rould obtain with $17 / 8$ inch ceiling insulation, and no wall insülation or storm windows (points $A$ on the figure).

The residences built prior to 1970 were designed for a level of thermal performance typical of the point $A$. With the issuance of the 1971 FHA Mirimun Property Standaras the insulation levels of residences affected by these standards was substantialny improved;" but these standards do not require storm windows. Thus, for the most of the extant residences in the colder climates of the U.S.A. and for a great nuniber of those yet to be built, application of storm windovis and insulation could reduce direct heat loss through walls by appreximately 40 percent.

Figure 2 shows Moyers calculation of net savings to the consumer, realizable through insulation and storm windows. There are several observations on these data which bear mention. First, not only is it economically attractive to install insulation and storm windcws, but the economically optimal level of insulation for residences in cold climates is found to be the extreme of the range of insulation which Moyers considered ( $31 / 2$ inches of wall insulation, 6 inches of

*Federal standaras have a direct effect on approximately 35 percent of new construction; the indirect effect of Federal standaras on residential construction is much larger than 35 percent. 
ceiling insulation glus stom wincows). Second, the data show that not only the net savings at the cconomic optimal condition but the cliaracter of the ontimaj. roint is extromely sensitive to the price of energy; in Figure 2 the only difference between gas and electric heat is price. As the price of enerby gocs up, small departures from the optimal conation, as represented in Figure 2, can cause large decreoses in net ammal savings. In fact, the true economic optimal design for either electric leating or heatjing with higher priced gas, may actually ve found at some greater Ievels of insulation and cortrol of fenestration than the extreme of the range show in the figure. Of course, to install more than 3 I/2 inches of wall insulation would require either modifying the wall cavity or devising some insulation system which could be mounted on the wall rather than in it. Either of these steps might be costly; but, with rising energy prices being a certainty in the future, the character the data in Figure 2 sugesests that it might not be too soon to start considering these steps.

During the past fer àcades energy prices have increased at a slower rate than prices of construction and other prices; relative to other items energy has been an increasingly good bargain. Thus, if it is now economically justifiable to install insulation and storm wirdows, it was even more easily justified in the past. The fact that insulation was not widely used in the past illustrates that the rational economic criteria of life cycle cost have not, as a rule, deen effectively applied in housing purchases. We will return to this point later. 
The selection of builaing equipncmi, is anothor mportant aspect

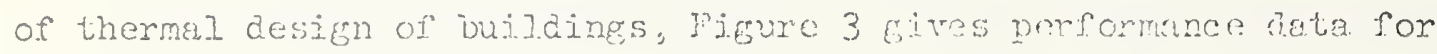
eir conditioners of various rated capicity and price (5). The power corsumption rate is the ratio of cooling aelivered to electrical energy consumed by the device. Ajr conditioners of $4000 \mathrm{BJU} / \mathrm{hr}$. capacity have electrical energy wequirements mich decrease by approximately a factor of tro as the price increases by 35 gercent. On a life cycle cost basis, the least expensive unit to own is the one with the greatest initial price. The some general pattern, with only minor exceptions, can be found in the units or higher rated capacity. These data prompt several observations. First, as with insulated housing, the units with the lower initial price tend to sell very well even though they may be, in the long mun, more expensive to own; rational economic criteria are not commonly aplied to building equipment. Second, since the market is and has been much more sensitive to initial price than to line cycie costs, tho equipment manufacturer is prone to desigr in high consunption in order to recuce initial price. One interpretation of Figure 3 is that by aproximately doubling the energy consumption of a $4000 \mathrm{BTU} / \mathrm{hr}$. air conditioner one con reduce its price by approximately 35 percent. Thus, a great deal of the building equifment in service today, which was bought because of low initial price, makes rather ineifective use of energy.

Corstmaction proctices in implementing design have a very important effect on energy use in buildings. Figure 4 shows tro scanning thermographs of insulated riall test panels subjected to $0^{\circ}$ Tr on one side and $70^{\circ} \mathrm{F}$ on the other. A differential pressure of $33 . / 2$ inches of water 


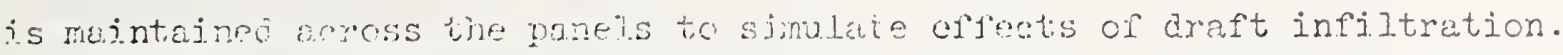
In the themographs the jight areas are wam and the dark areas cold; the dork vertical bne appear whore the thermoprepiny resolves the studs in tile val. The test wall. in Fifure $4 \mathrm{~b}$ was made wjth a deliberate construction lidw corsisting of displacement of the edige of each stud $1 / 8$ inch outboard of the plate. The cold wall area represented by the dark fringe in the fjgure js caused by infiltration through this flaw. The net effect is sufficient to reduce the effective insulation of the wall signifiamtly below its design level. As energy becomes more costly it wili probably become worthwile to make the extra investnent required to attain more careful practices in consiruction, or to find. designs for wall insulation etc., which are not so sensitive to minor corstruction flaws.

Occupani practices in builaings are very important in attaining effective use of energy. For exemple, in a rocent public discussion it was noted that in government office builaings of essentially the sare design and construction, situated in similar clinates and used for similar purposes, energy consumption can vary by as much as 40 percent (12). Also, careful management of large refrigeration plants has been shown to conserve as much as 12 percent of the electrical energy required by the plent, without sacrifice of plant performance (J.3).

The maintenance of home heating equipment is also an item of great importance. The small scale combustion equipment used for home furraces and hot water heaters is designed so that approximately 70 to 75 percent of the heat of combustion will be transferred to the hot water or air stream (as the case may be) 
when the equipment is clean, in proper adjustrient and operated in steady state. However, transient operation can produce soot formation which can ereaty reduce the effectjveress of this equipment. Sample field observations and theoretical. cstimates of the effects of minor unattended items of maintenance indicate that the actual effectiveness of these small combustion units in field service may be in the range from 50 to 35 percent $(14)$.

If all that could be ecoiomically justified in insulation and fenestration of existing stmuctures and new constmiction were actually to be done, if all that coula be done to operate buildings effectively were actually to be done, if economically justifiable application of available technology to heat recovery in ventilation systems vere actually Inede, if careful use of ventilation and illumination were maae, then it would not be unreascnable to expect that as much as 40 percent of the primary fuels now used to support building requirements could be conserved. Moreover, these fuel savings would not require sacrifice in the quality of the builaing environment, nor would they require unjustified costs. On the contrary, the measures spoken of here could, if adopted, reduce net life time operating costs of buildings.

\section{(b) Energy Use in Industry}

The use of energy at points of consumption in industry has been mach less well studied than energy use in buildings. Until quite recently it has beer assumed that industry must make the most effective

*It is reemchasized that we are concerned here with onerations which consure energy rather than energy conversion operations such as electric power generation. 
posible use of energy, because to io otherwire would not be mroribuble. This assumption has now been reexamined, and found to be iraccurate by industry itself. For example, merely by plufking leaks in air and stean lines, by providirg steam at the pressures and temperatures required, and by instituting other straightforward energy managemeni practices, consultants have been able to ceduce the fueI requirements of large industrial plants by 7 to 15 percent (8). Present efforts for energy conservation through application of waste heat management heve hardly scratched the surface of this field. In addition, redesign of process equipment offers a great potential for energy savings. Experts in metal processing have estimated that if full application of presently known economically justifiable techology were to be made in furnace design, heat soaking pit design and thermi management of processes, the overall fuel requirements of steel making covid be reduced as much as 20 percont (11). Recent redesign of vacuum furnaces, entailing improved vacuum insulation and the use of direct combustion with a heat pipe to provjde heat, in place of electrical heating, has reduced the fuel requirements of vacuum furnace operations by 75 percent $(9)$

Newly emerging developments in thermal process design are also noteworthy. For example, paper making accounts ior approximately 2 percent of the total primary fuel consumption in the U.S.A. (2). The largest part 


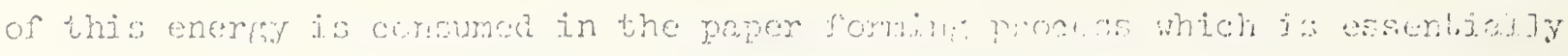

a drying operation. Traustriazists in whope. (15) and in the U.S.A. (I6) arc aevelopjng techniques for "hitgh consistency" rapen forming. Using these techniques, one berins the paper making process with a thicker slurry; there is less water to ary out of the paper and thus less energy is required. For example, for certain types of paper it is possible to change from a slurry having $1 / 2$ percent solias at the outset to one having 3 percent; thus only $1 / 6$ as much water neeâ be removed from a given unit of paper. Engineers who have studied these processes have estimated that as much as 55 percent of the energy requirements of paper formine could be conserved through implementation of high consistency forming techrology.

Cement production also accounts for approximately 2 percert of the prinary fuel consumption in the U.S.A. The largest part of this energy is used as direct heat in the cement kiln. Modern cement kilrs now being introduced on the Western European market are capable of cutting the fuel requirements of kiln operations by approximately 30 percent. More advanced prototype kilns are under development in the U.S.A. These kilns employ fluidized bed technology to achieve rapid heat transfer and intimate mixing. They have the capability of yielding even greater reductions in fuel requirements for kiln operations (17).

The data cited above support the belief that the practices and equipment used at the points of energy consumption in industry can be substantially improved, ard that in many cases the improvements can be economically justified. In the case of industry, economic 


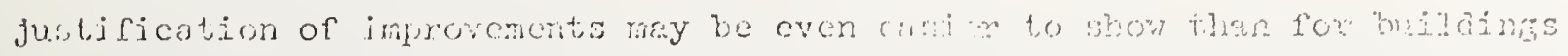

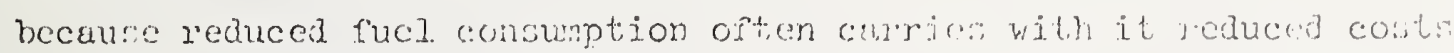
of pollution control. In additjon, in mary instances rejesign of thrmal process equicment and institution of more careful enercy ranagement procedures often enhances productivity as wel_l.

Given the instances cited above, and the instances given in the current literature $(8,9,10,11)$ it would not secm unreasonable to assume that if full economically justifiable application of known energy management techniques were to be made, and if full economically justifiäie adoption of the improved equipment which now exists in proven form vere to be carriea through, the primary fuel requirements of cnergy consuming processes in industry might be reduced by as much as 30 percent. It is acknowledged that this estimate cannot be defended by statistical methodology as can an estimate for the potential of energy conservation iu bijlaings. While data are too sparse to support statistical estimates of potential energy wavings in industry at high confidence levels, an ecoronically justifiable 30 percent reduction in primary fuel requirements for energy consuming processes of industry would seem to be a realistic goal to set for application of effective technology to these processes. 


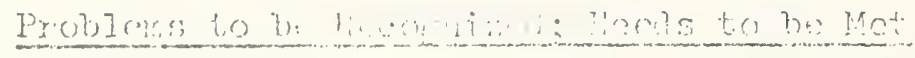

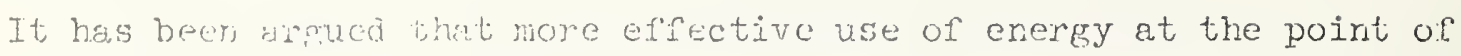
consumition is; both technicully feasible and economically justifiable. If this is true, and if it has been true for sometine, why has not adoption of more effectivo equignent, practices, vuilding insulation, etc., been widespread. This js a complicated question to which there is no single simple answer. Nevertheless, two combined forces can be seen to have had widespread effect. First, the deliberate efforts in the past to provide high-quality energy in abundance and at minimal price appear to have encouraged excess consumption. Second, in the economic criteria for justification of acquisition of buildings, heating equipment, industrial plant equipment, and other apparatus used at the point of energy consumption, a much hieher priority has usually been assigned to initial cost than to Iife term operating costs; in particular, energy costs for life term operation have often been neglected.* Jhus, in order to satisfy the criterja of the marketplace, builders and equipment manufacturers have been prone to aesign high energy consumption into their products in order to reduce first costs. $\%$

A major reason why first costs are a powerIul influence in the building maxket is that most commercial and residential construction starts are speculative. Often the original builder does not know who the first owner of the building will be. In this situation, the builder who

*It is important to recognize that we are speaking of items of equipment at the point of energy consumption, not of equiment for energy conversion such as is power generation.

**Recall Figure 3 ana earlier remarks pertaining to it. 
buj] ds; for exfective use of encsgy, but at higher cont, can run very sericus risks. In comercial hijaires, the buinder and first purchaser may be acquainted, but Jife term costs are not i dominant consideration. Often the goal of the first purchaser is eqeculative. The potential gain in value of the developed real. estate may be a much more important aspect of the speculation than the crergy costs of operating the building. In addition, ever for those cases in which the first purchaser of a building may be aware of the potential long-term gains relizable through somewhat greater initial investment for better thermal performance, the financial institutions upon which the construction market depends are not presently prepared to deal with financing buildings in such a way as to recognize the trade-offs betweer greater initial investment and savings in operating costs.

Industrial plant equipment used at the point of energy consumption is subject to similar criteria as buildings. The manager of ar operating unit of industry is comonly responsible for his unjt's capital budget and maintenance costs, and above all, he is responsible for his units production. However, the costs of fuel or power are not often high priority responsibiiities. In fact, in many industriel accounting systems, enerEy costs are carried as overhead. Thus, even when an industrial unit manager recognizes that acoption of more effective equiment in his unit can yield econornic benefits for his firm, the criteria required to justify the equizment may no' be arailable to him; the justification may require modifications at several ievels of management above his unit. This does not necessarily pose an absolute barrier to introduction of more effective equipment, but it 
cortainly can uct to returk that puocsis. To modify ocomic exiteria to edmit more efrective encrgy consuming eguipnent requires, ati the very minimum, rceognitjon on the part of highor manargoment thit, more effcctive use of energy is an important objective. In the recent past, energy prices rose less than other prices and energy progressively became a better and better bargain. It jis not surprising that industrial management has not always seized upon the technical opportunities to improve the effectiveness of industrial energy consuming processes. But the era of inexpensive energy has past, and management attitudes toward efiective use of energy may change significantly in the near future.

In addition, it should be recogrized that industrial management is a.ltays presented with a variety of problems and onportunities. Management must decide how best to employ the resources at its, disposal to meet these. In the view of industrial mangenent the potential for increasing profitabjility through investinfs in more effective equipment and practices for energy consuning operatjons, nay not have appeared as attractive an opporturity for utilizing the funds and talent available as, say, modifying certain of the corporations own management procedures. Indeed, the householder and the consumer undoubtedly make very similar judgments when it comes to investing in adaitional quality of construction or appliances in order to attain savings in life term costs through effective use of energy. To the private citizen, the attraction of retaining liquidity rather than investing in hisher quality buildings may be quite powerful. In any event, the point to be recognized here 
is that adoption of erfective cnergy consuming equjunent often requires increased initial investment, and this investment must be shown not only to pay, but also to compare favorably with other available options for investrnent.

It may be that industrial managers and consumers have recognizeả the technical potential for effective use of energy and have properly evaluated the associated investment opportunity. Somehow one doubts this; the present evidence of successful and profitable applications of effective practices such as vaste heat management indicate otherwise. Rather, one suspects that the technical and economic implications of effective equipment and practices at the point of energy consumption have not been fully recognized in the past. One also suspects that this lack of recognition has constituted a flaw in the mechanisms of the marketplace. One of the principal needs of conservation efforts for the future is the institution of an effective market-mechanism to facilitate the adoption of efficient equipment and practices at the point of energy consumption. The requirements for instituting such a market-mechanism are numerous. They may include regulatory measures, which are often discussed in the press, but which are beyond the scope of the present writing. In addition to these are the following specific needs.

Information

All who take part in the marketing of energy and in consuming energy need to be apprised of the technical options for more effective use of energy and the economic implications thereof. Warketplace-mechanisms do not work effectively unless the participants in the market are informed. 
In particular, there is reed for data on incremental cost benefit ratios of various options for improved effectiveness in utilization of energy; the relative merits of insulation as opposed to control of infiltration in buildings need to be determined. Also, realistic formulae by which trade-offs between initial investment and operating costs might be included in criteria for financing construction or new industrial plant equipment are required; these should take into account estimates of energy price increases. Other items of information obviously suggest themselves to those who consider this issue.

Effective Technology

At the base of all efforts to improve use of energy at the point of consumption is application of effective technology. Some of the examples cited above have shown that technology can be devised for more effective use of energy. In adition, in those instances where life term costs of energy utilization at the point of consumption have been determined, the minimum 'Iife term cost has been found to be attainable by investing initially in equipment which is at or very near the top of the price-and qualityorange available on today's market. This suggests that the technical potential for designing effective performance into the equipment used at the point of energy consumption has not been fully exploited. Had it been fully exploited, there should be some very high performance equipment on the masket which would be suitable for very long-life operations (say forty years) but which would be economically unatractive for shorter life applications (say ten years). But this does not appear to be the case. As a specific example, one may consider electrically driven heat pumps. Comparing the measured 


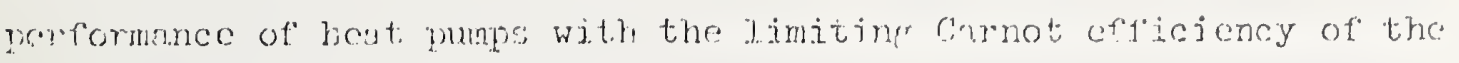
device, one finde that oxistine leat pumpa, operating under mije clinatic conditions where they are most, effective, attajn only aporoximately 5 percent of their limiting efficiency. Under morc severe climatic conditions, in wich their actual measured perfomance is rather poor, existing heat pumps attain approximately 20 percent of their limiting efriciency. Power generation devices, on the other havd, attain 70 percent and more of their limiting efficiency. The basic technology used to approach the limiting efficiency in a power generation device is not at ail unsimilar to that required for design of a heat pump, and by appropriate design, one could produce a more effective heat pump. Of colirse, until the value of such an improvement is appropriately recognized in the marketplace there will be little incentive to do so.

Two major causes of incfective operntion of devices and processes at the point of enerey consumption are faulty heat tranifer and mixing. Many special techniques exist to overcone these problems, but up until now they have not found many applicatjons outside of energy conversion operations. Among these techniques are fluidized beds, heat pipes, induced vorticity for improving inixing processes or combustion, jet inpingement, and heat recovery apparatus. These techniques can be most useful in improving effectiveness of energy consumption. The application of these techniques in an econonically justifiable way should be encouraged. 


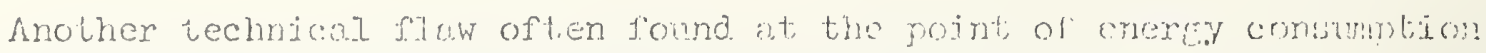
is detcrioration of equiment through 1.8\% meintenanee. This problem coukd be attacked in at least two ways. The houscholder should be apprised of the fuel costs he wiIl. ultimately pay is he permits deterioration of the hert transfer surfaces of his furnace or hot water heater; he should be informed as to when and how to apply maintenance procedures. In adition designers of equipment should devote some serious efforts to design for maintainability. The general principles of informing the user, and designing for maintainability obviousiy also apply to nost other items used at the point of energy consumption.

Measureinent Capabjility

As sound technology is necessary to irprove eifectiveness of energy consumption, sound measurement capability is required to support the technology. The capability to measure the thermal perfornance of buildings in the rield and to determine that the potential of the themal design has actually been realized is a basic requirement for the support of any market system to facilitate investment in effective thermal performance of buildings. Also, the capability to measure the pexformance of building equipment, major eppliances, and items of industrial equipinent, in such a way as to reflect actual conditions of field service, is needed to provide those who wish to invest in higher quality performance with the information required to make rational decision,. The present standard test methods which are applied to most major appliances and iterns of building and industrial equipment are not constructed so as to reflect the 
actual duty cycle to which an sppliance is subject in the field. r'he mantenability of trese items is, usual.jy, not covereo by standaras: and the susceptibility of equjpment to undtended naintenance is rot, usuliy detemined. In fect, the efficiency of ecuipment is seldom. measured in a standard test method. Reliable and realistic information pertaining to equipment performance is a basic requirement of those who must decide which equipment to purchase. Our present capabilities to provide this information require substantial improvement to support effective efforts for conscrvation.

Practices of Assessment and Precictive Modelinr:

Although a great deal of work has begun to assess energy use and to corstruct predictive energy flow models, much of this work relies upon trend extrapolation, a technique which is based upon the assumption that the future must resemble the past. In particular, the majority of energy assessment studies and predictive modeling efforts initiated to date have cortained the assumption that the technical potential for improvement in practices at the point of energy consumption have been exhausted. As ras bee: shown, this is not the case. Moreover, in a very significant respect the future will not resemble the past; primary energy sources will no longer be abundant and inexpensive. With conservation now emerging as an inevitable issue for the future, almost all predictive models are used to study options for conservation. But, a predictive model based upon the assumption of "frozen" technology at the point of energy consumption can yield but one conclusion on conservation, which is that 
conservation cen be achievec only through curtailiment. This is simply not tmas. Ihre models have vielded un inaccurate conclusion becuuse they dia not adires the complete set of questions.

It would be very useful to have predjctive models which admit tochnological flexiojilty at the point of energy consumption. Such models viould be especially helpful in eva.Juating the balance of investment in development of new energy sources, effective technology at the point of energy consumption, and systems of energy curtailnent. Such a capability for evaluation is required if anything approaching optimal utilization of those resources which can be brought to bear on energy problems is to be ochieved.

Regarine predictive models, the importunce of analysis of direct consumption of energy-..as opposed to f'low of energy through the econorny-m may have been underestinated. It is at the point of energy consumption that one can apply technical improrements, and studies of energy flow tend to burden one sector of the economy. With the ineffective practices of another. Studies of energy consumption need to be carried out so as to reflect the quality as well as the quantity of energy consuned, and to compare these with the quality and quantity of energy actually required at the point of consumption. Since high (thermodynamic) quality fuels are at the center of energy problems, the measurement of quality is an extremely important, but largely underestimated aspect of assessing energy consuming practices. An important illustration of this point is the heat pipe vacuum furnace described earlier. This furnace is more effective in its use of energy because it wastes less of the themodmemic availability of the enerey source than jid its predecessor: 
Conclusicri

The techical and acomomo opportunities for energy conservation through improved aftectiveness of use of encrgy at the point of consumption are only now beginning to be recognized. If appropriate steps are taker now to apply technology effectjvely to energy consuming processes and to instj.tute approprjate market mechanisms to further these applications, measures for energy conservation, which appear to be eventually necessary, can be comprised of an appropriate balance between more eifective use of energy and curtailment. The ultimate consequences of cnerer conservation need not be so dire as might obtain under conservation measures which depend entirely upon curtailment. Woreover, since other nations of the world will certainly face energy problems quite similar to those facing the U.S.A., the, technology which we institute for effective utilization of energy at the point of consumption in the U.S.A.--especially for therrnal processes of industry and for building equipment--may very well be attractive and marketable in international trade. 
Pjgure 1: Woyer's calculation of the eleci of insilation and stom windows on heat loss from typical residences. 


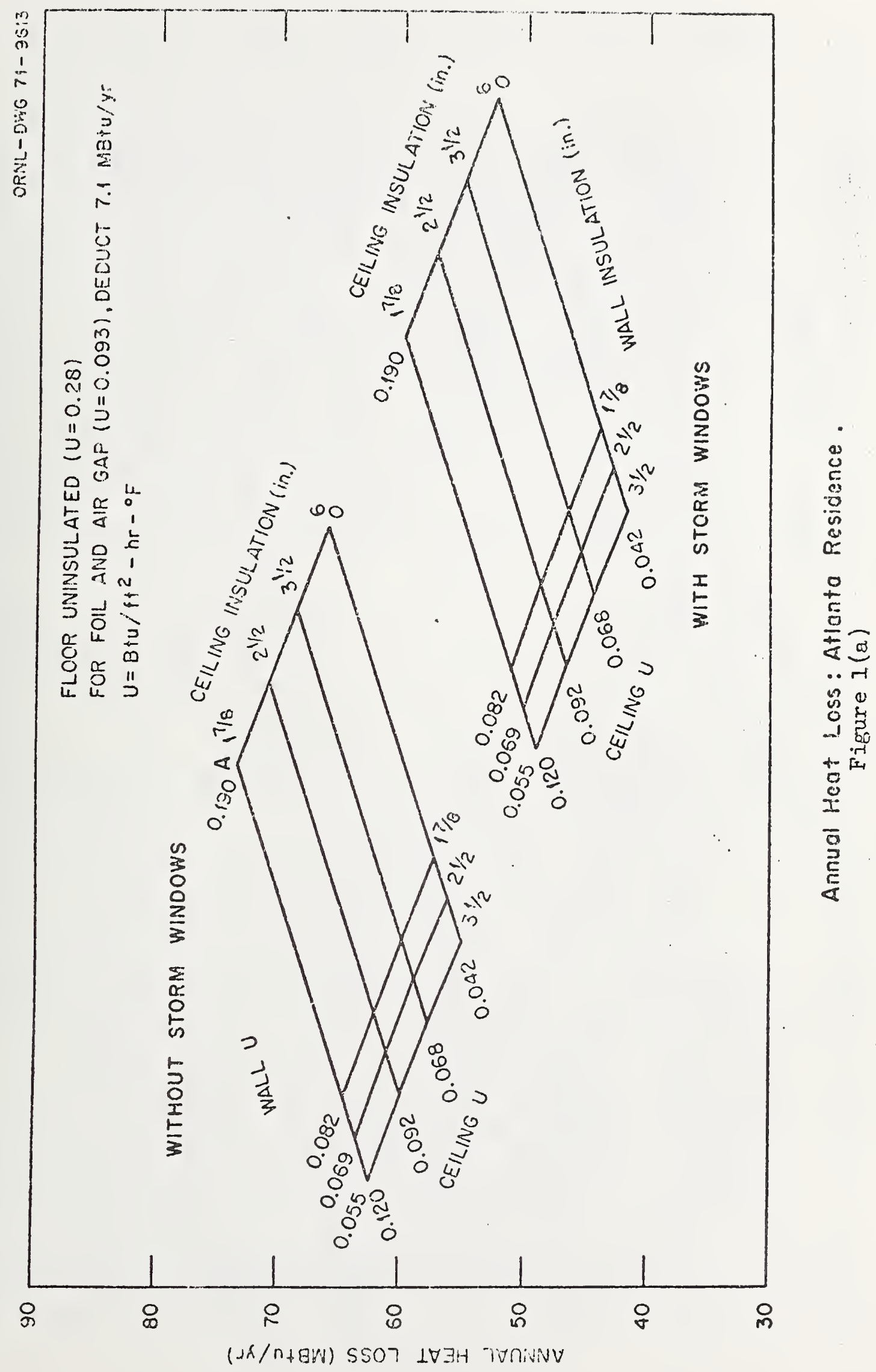




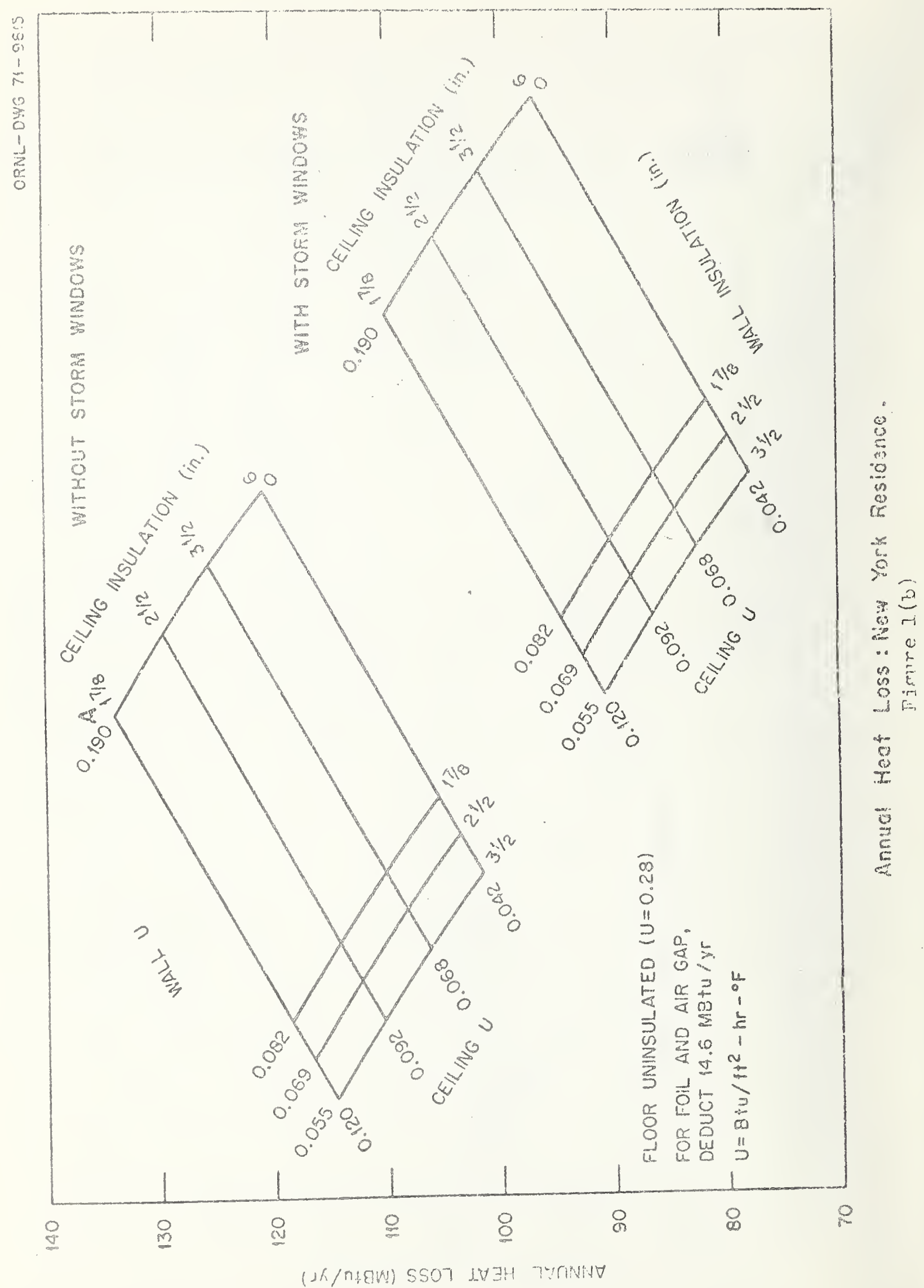




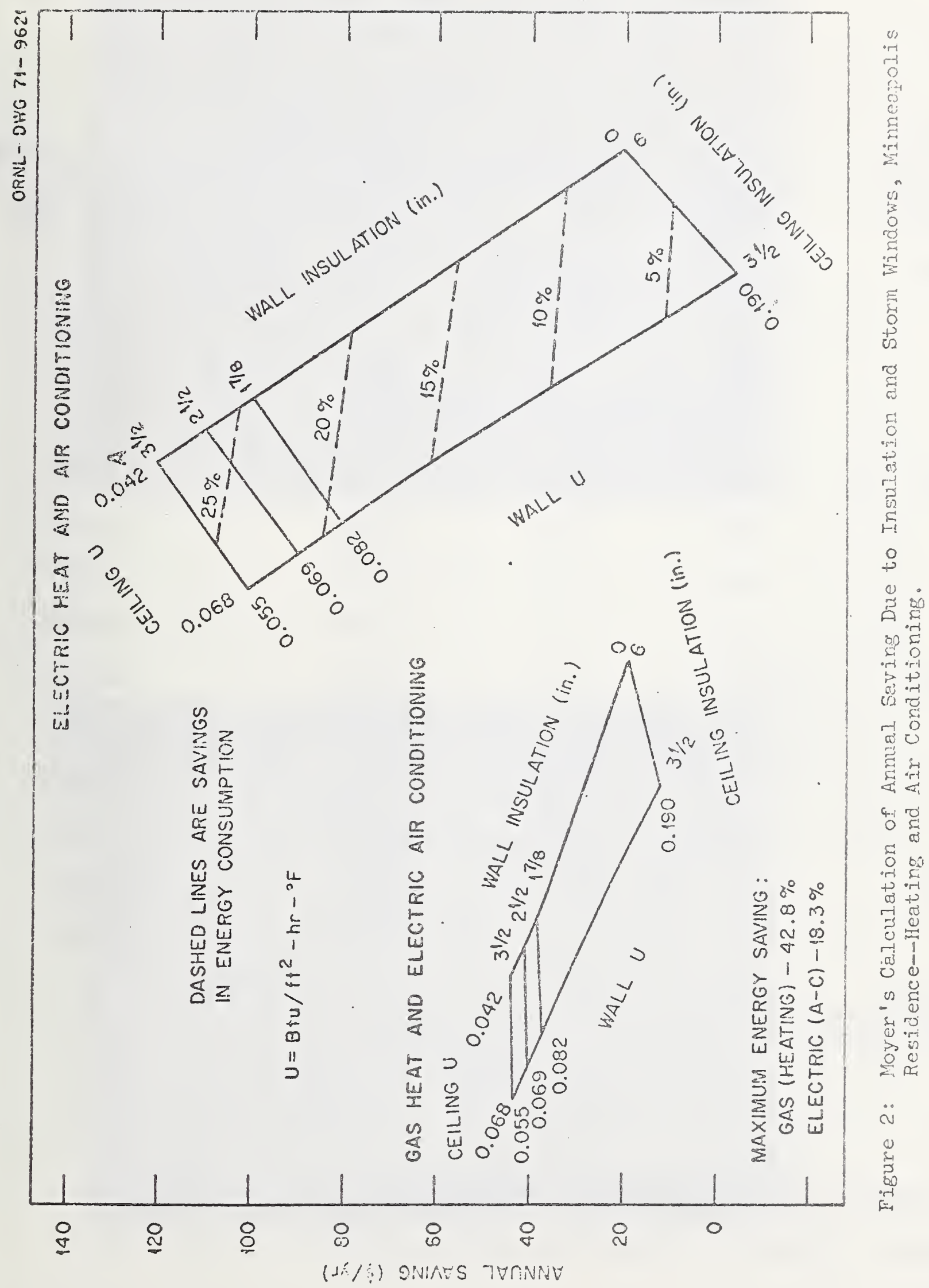


AIR CONDITIONER PEREORMANCE VARIATIONS

RATED

COOLING

CAPACITY

BTU'S

4000

5000

6000

8000

24,000

(CENTRAL)

,
RATED

$\frac{\text { CURRENT }}{\text { ANAS }}$

8.8

7.5

7.5

5.0

9.5

7.5

7.5

5.0

9.1

9.1

7.5

3.5

12

12

13.2

1.5. 4

17.0
POWER

COISUMPTION

REYAI!
VALUE
$\$$

100

110

125

835

$\$ 20$

140

150

165

160

170

170

180

200

220
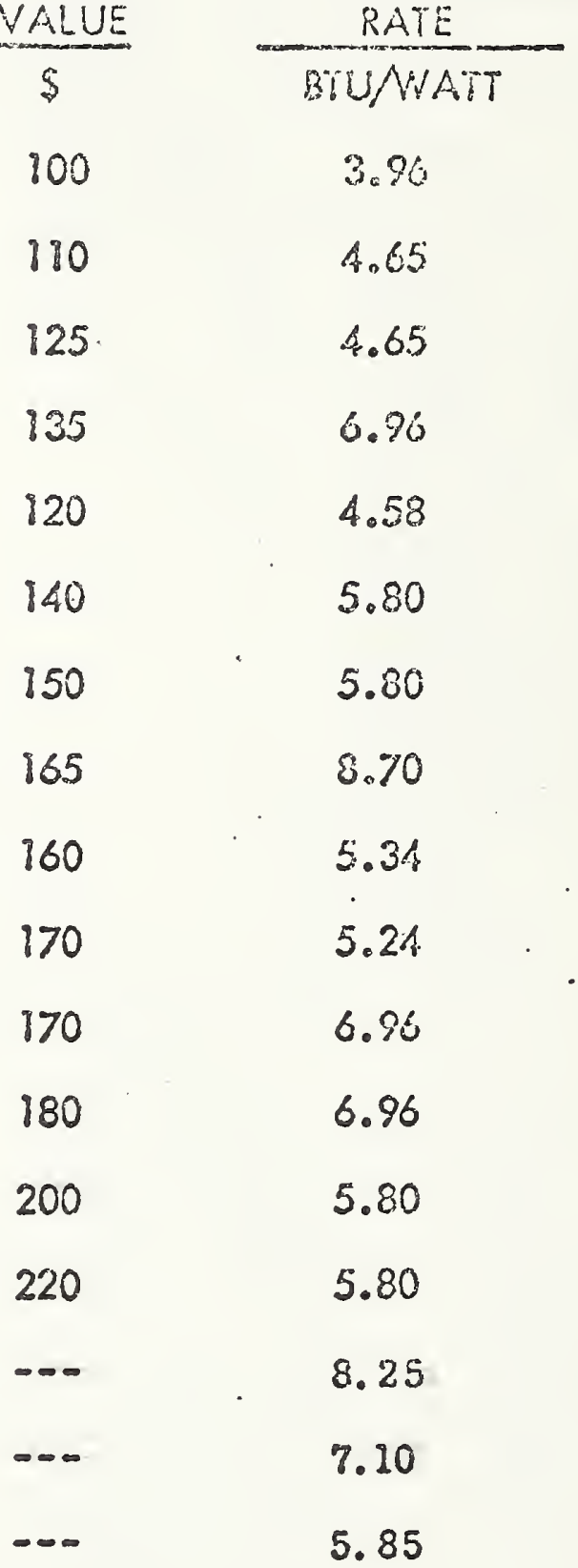

3.96

4.65

8.65

0.26

4.58

5.80

5.80

8.70

5.34

5.24

6.98

6.96

5.80

5.80

8.25

7.10

5.85
10 YEAR TOTAL"

77.70

81.45

67.25

74.90

68.20

70.20

59.80

67.30

68.90

$6 i .80$

63.50

67.30

67.80

* based on 880 operating hours per yeAr

Figure 3 : Performance lata for Air Conditioning Units 


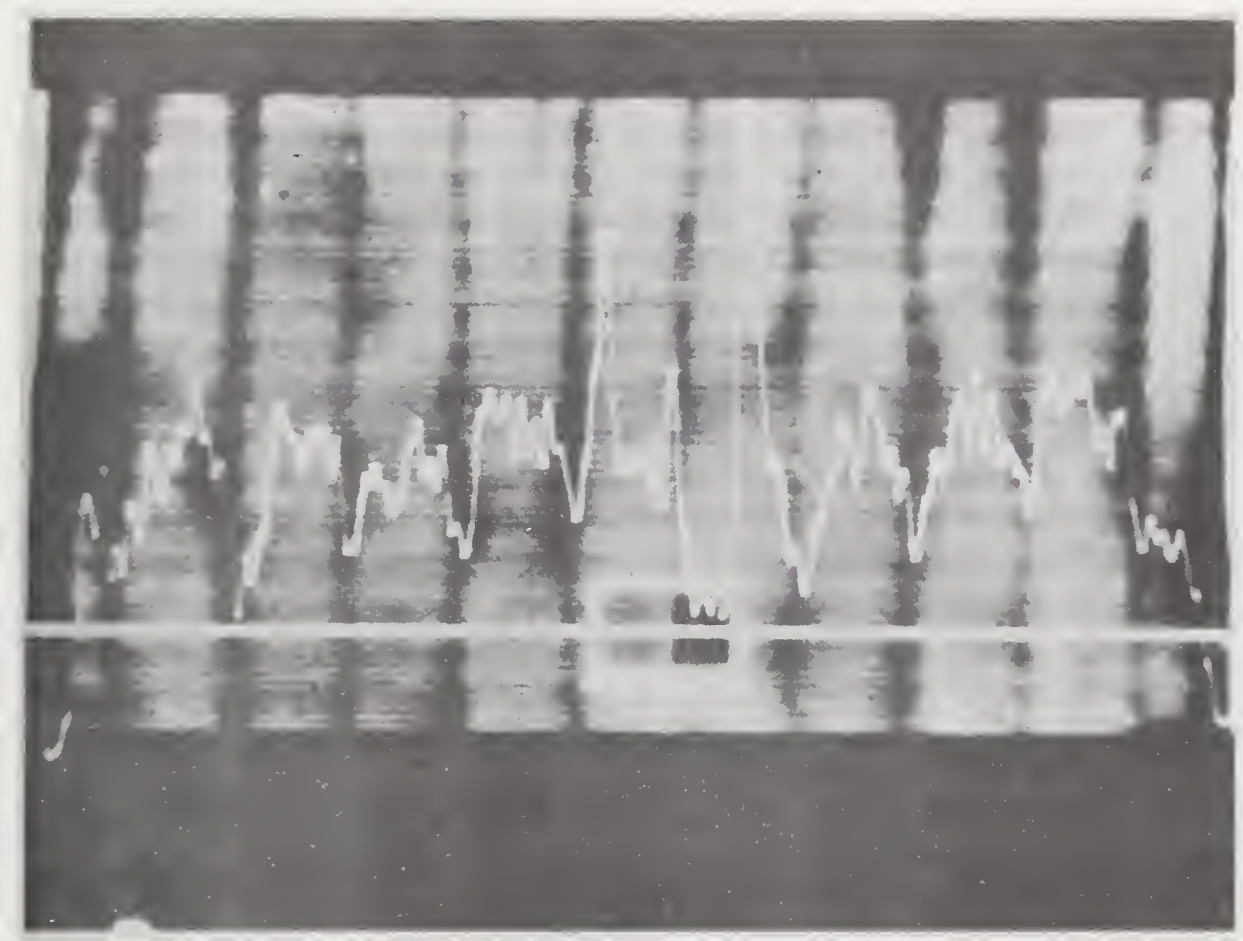

Figure $4(a)$
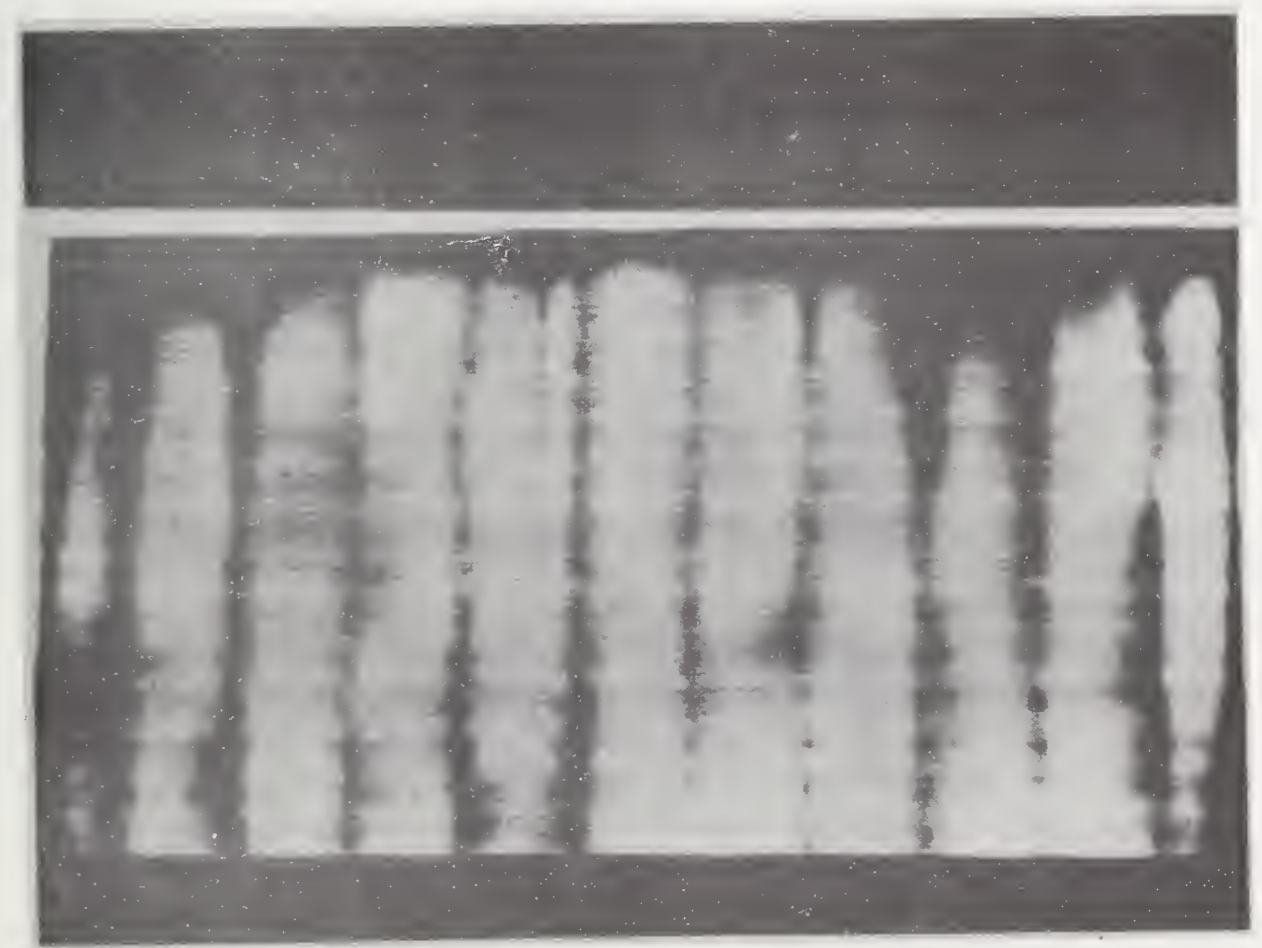

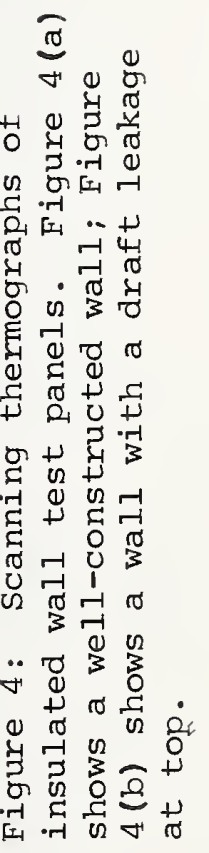

Figure $4(\mathrm{~b})$ 
Trable 1

FNERGY CONSUATTIG: EN THE UNITED STATES BY ENO USE

$1960-1963$

(Trillions of $B$ tu and Perceni pex year)

Fercent of

\begin{tabular}{|c|c|c|c|c|c|}
\hline \multirow{2}{*}{ Sector and End Use } & \multicolumn{2}{|c|}{ Consumption } & \multirow{2}{*}{$\begin{array}{l}\text { Annual Rate } \\
\text { of Growth }\end{array}$} & \multirow{2}{*}{ National } & \multirow{2}{*}{$\frac{1 \text { Total }}{1968}$} \\
\hline & 1960 & 1968 & & & \\
\hline \multicolumn{6}{|l|}{ Mesiciential } \\
\hline Space hoating & 4,818 & 6,675 & $4.2 \%$ & $11.3 \%$ & $13.0 \%$ \\
\hline Water heating & 1,159 & 1,736 & 5.2 & 2.7 & 2.9 \\
\hline Cooking & 556 & 637 & 1.7 & 1.3 & 1.1 \\
\hline Clothes drying & 93. & 208 & 10.6 & 0.2 & 0.3 \\
\hline Refrigeration & 369 & 692 & 8.2 & 0.9 & 1.1 \\
\hline Air conditioning & 134 & 427 & 15.6 & 0.3 & 0.7 \\
\hline other & 809 & 1,211 & 5.5 & 1.9 & 2.1 \\
\hline Total & 7,968 & 11,616 & 4.8 & 28.6 & 19.2 \\
\hline \multicolumn{6}{|l|}{ Commercial } \\
\hline Space heating & 3,111 & 4,182 & 3.8 & 7.2 & 6.9 \\
\hline Water heating & 544 & 653 & 2.3 & 1.3 & $1 . \bar{\lambda}$ \\
\hline Cooking & 98 & 139 & 4.5 & 0.2 & 0.2 \\
\hline Refrigeration & 534 & 670 & 2.9 & 1.2 & 1.2 \\
\hline Air conditionirer & 576 & 2,123 & 8.6 & 1.3 & 1.8 \\
\hline Feedstock & 731 & 984 & 3.7 & 1.7 & 1.6 \\
\hline other & 145 & 1,025 & 28.0 & 0.3 & 1.7 \\
\hline Total & 5,712 & 8,766 & 5.4 & 13.2 & 14.4 \\
\hline \multicolumn{6}{|l|}{ Industrial } \\
\hline Process steam & 7,646 & 10,132 & 3.6 & 17.8 & 16.7 \\
\hline Electric drive & 3,170 & $4,79 ! 1$ & 5.3 & 7.4 & 7.9 \\
\hline Electrolytic processes & 486 & 705 & 9.8 & 1.2 & 1.2 \\
\hline Direct heat & 5,550 & 6,929 & 2.8 & 12.9 & 11.5 \\
\hline Fecd stock & 1,370 & 2,202 & 6.1 & 3.2 & 3.6 \\
\hline Other & 118 & 198 & 6.7 & 0.3 & 0.3 \\
\hline Total & 18,340 & 24,960 & 3.9 & 42.7 & 41.2 \\
\hline Transportation & & & . & & . \\
\hline Fuel & 10,873 & 15,038 & 4.1 & 25.2 & 24.9 \\
\hline Raw materials & 241 & 140 & 0.4 & 0.3 & 0.3 \\
\hline Total. & 11,014 & 15,184 & 4.1 & 25.5 & 25.2 \\
\hline National total & 43,061 & $60,526$. & 4.3 & $200.0 \%$ & $100.0 \%$ \\
\hline
\end{tabular}

Sote: Electric utility consumption has been allocated to each end use.

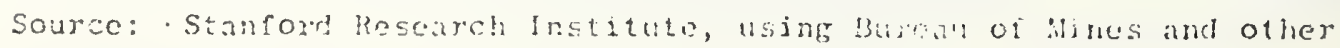
sources. 


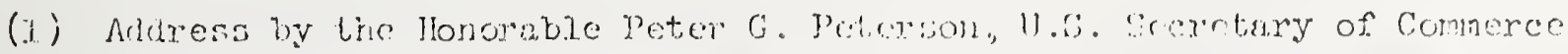

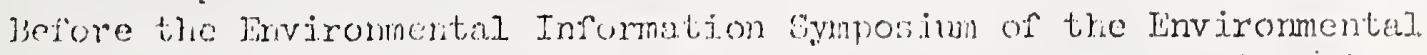
Protection Agency, rinejnnatj Corvention Center, Cincinnati, Ohio, Sept. 27, 1972 .

(2) "Patterrs of Energy Consumption in the United Stetes" (Stanford Kesearch! Institute, January 1972).

(3) "Energy Conservation Through Effective Juilization," National Eureau of Stancards Report No. INBSIR 73-102, February 19'3.

(4) Dubin, F.S.: "A Wiser Use of Flectricity and Energy Conservation Through Building Design," Building Systems Design, Jaruary 1973, pp. 8-14.

(5) "Subpanel Reports on Total Energr Systems, Urhan Energy Systerns: Residential. Energy Consumption" "submitied by the Department of Ilousing and Urban Development to the Committee on Inergy Research and Development Goals, Federai Council on Science and 'lechnology, Ju].y 1.97?.

(6) Moyors, John C.: "The Value of Thernal. Tnsulation in Residential. Construction: Economics and the Conservation of Jnerery" (Oak Riafe Netional Laboratury, December 3.971, p. 28).

(7) "Iripact of Improved Thermal Performance in Consejving Energy" (National Minera.l Torld. Insulation Assoc., Inc., Apri]. 1972, p. 35).

(8) "Soving Energy By Cutting Needless Loss," Business Week, Nov. 18, 1.972, ข. $30 j$.

(9) Shefsiek, Paul K. and Lazaridis, Lazaros J.: "Development of a Natural Gas Fired Feat Pipe Vacuum Furnace" to appear in Natural Gas Research and Technology, 1972.

(10) Rosenberg, R. B.: "The Future of Industrial Sales" (Institute of Gas Technology Publication, May 1972).

(11) Nesbitt, J. D.: "Improving the Utilization of Natural Gas in Major" Steel Mill Applications (Institute of Gas Technology Publication, April 1972).

(12) Grot, R.A. ana Socolow, R.H.: "Energy Utilization in a Residential Comunity," Princeton University. 


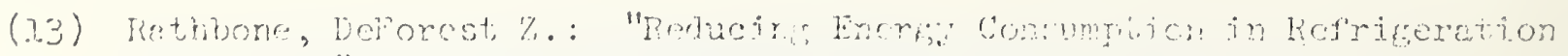

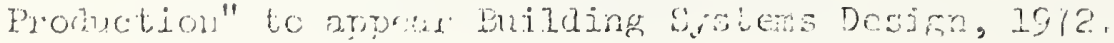

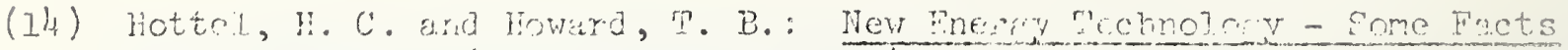

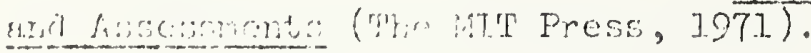

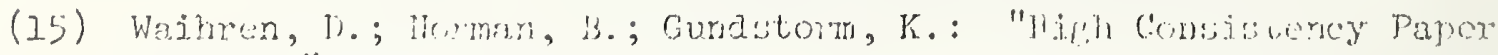
Forming," Japer "irire Tourneil.

(16) Private Communication, Dr. O. J. Kalras, Jjrm, Mass.

(17) Private Communication, Dr. L. Lazaridis, Waltham, Mass. 


\begin{tabular}{|c|c|c|c|}
\hline $\begin{array}{l}\text { U.S. DEPT. OF COMM. } \\
\text { BIBLIOGRAPHIC DATA } \\
\text { SHEET }\end{array}$ & $\begin{array}{l}\text { 7. PUELICATEN OR REPORT NO. } \\
\text { NESIR } 73-202\end{array}$ & $\begin{array}{l}\text { 2. Sov' Accession } \\
\text { tho. }\end{array}$ & 3. Recipient's Accession No. \\
\hline \multirow{2}{*}{\multicolumn{3}{|c|}{$\begin{array}{l}\text { 4. TITLE AND SLBTITLE } \\
\text { CONSERTATION VIA EFFECTIVE USE OF ENERGY AT THE POINT } \\
\text { OF CONSUMPTION }\end{array}$}} & $\begin{array}{l}\text { 5. Publication Date } \\
\text { April 11, } 1973\end{array}$ \\
\hline & & & 6. Performing Organzzation Code \\
\hline \multicolumn{3}{|l|}{$\begin{array}{l}\text { 7. AUTHOR (S) } \\
\text { Charles A. Berg }\end{array}$} & $\begin{array}{l}\text { 8. Performing (1equanizution } \\
\text { NBSIR } 73-20^{\circ}\end{array}$ \\
\hline \multirow{2}{*}{\multicolumn{3}{|c|}{$\begin{array}{l}\text { 9. PERF ORWING ORGANIZATION NAME AND ADDRESS } \\
\text { NATIONAL BUREAU OF STAND ARDS } \\
\text { DEPARTMENT OF COMLERCE } \\
\text { WASHINGTON, D.C. } 20234\end{array}$}} & $\begin{array}{l}\text { 10. Project/Task. Hork Unit Nu. } \\
4000910\end{array}$ \\
\hline & & & 11. Contract/Grant No. \\
\hline \multirow{3}{*}{\multicolumn{3}{|c|}{ 12. Sponsoring Otganizacion liame and Address }} & $\begin{array}{l}\text { 13. Type of Report \& Period } \\
\text { Covered }\end{array}$ \\
\hline & & & Final \\
\hline & & & $\begin{array}{l}\text { 14. Sponsuring Agency Code } \\
\text {. }\end{array}$ \\
\hline
\end{tabular}

\section{SUP PLEMENTARY NOTES}

16. ABSTRACT (A 200-nord or less factual summary of most significant information. If document includes a significant bibliography or itterature survey, mention it here.)

The practices and equipment employed at the point of energy consumption in buildings and in industrial processes permit excessive consumption of energy. It is estimated that if full application of the economically justifiable technical improvements presently available were mace to equipment and practices in buildings and industry, as much 25 percent of the cotaI primary fuel consumption in the U.S.A. could be conserved. The reasons why economically justifiable application of effective technology at the point of energy consumption has not been widely adopted in the past are considered. The needs to facilitate adoption of effective equipment and practices in the future are discussed.

17. KEY TORDE (Alphaberical order, separatec hy semicolons)

buildings; energy corservation; industrial equipment

18. AVAILABISITY STATEMENT

UNLARTED.

FOR OFFICIAL DISTRIBLTION. TO NOT RELEASE TO NIIS.

\begin{tabular}{|c|c|}
\hline $\begin{array}{l}\text { 19. SECLRITY CLASS } \\
\text { (THIS REPORT) } \\
\text { (UNCL.ASSIFIED }\end{array}$ & $\begin{array}{l}\text { 21. NO. OF PAST:S } \\
37\end{array}$ \\
\hline $\begin{array}{l}\text { 20. SWCURITY CLASS } \\
\text { (THSPACHO) } \\
\text { UMCI.ASHISIED }\end{array}$ & 22. Price \\
\hline
\end{tabular}




